\title{
Pelatihan Rancang Bangun Pembangkit Listrik Tenaga Surya Di Madrasah Aliyah Darussalam Parung Bogor
}

\author{
Sofitri Rahayu ${ }^{1}$; Andi Junaidi ${ }^{2}$; Hasna Satya Dini ${ }^{3}$; M. Imbarothur Mowaviq ${ }^{4}$; \\ Rudina Okvasari $^{5}$; Sugeng Purwanto ${ }^{6}$; Wawan Ridwan ${ }^{7}$ \\ 1, 2, 3, 4, 5, 6, 7 Program Studi Teknik Elektro, Sekolah Teknik Tinggi PLN \\ sofitri@sttpln.ac.id
}

\begin{abstract}
This activity is motivated by the growing technology of solar power plant (PLTS) as an alternative energy source because of the decreasing reserves of major energy sources (petroleum, gas, coal etc.)in the world. Indonesia's strategic position on the equator has a positive impact on the length of time the sun has received. The use of sunlight as one of the alternative energy sources has been widely done, one of the application is the solar home system. The design training of solar power plants was given to 40 students at the Islamic Boarding School of Madrasah Aliyah Darussalaam Parung Bogor. This training aims to introduce and provide skills in the field of designing solar power plant systems for small homes to students and to installed solar power plants at Islamic Boarding Schools Islamic Boarding School Darussalaam Parung, Bogor. The method used is by giving presentations and training to students and practice by installing solar power plants around catfish breeding ponds as lighting. The results obtained are in the form of the ability of the students to design and install a simple Solar Power Plant independently.
\end{abstract}

Keywords: solar cells, boarding schools, renewable energy

\section{ABSTRAK}

Kegiatan ini dilatarbelakangi dengan makin berkambangnya teknologi Pembangkit Listrik Tenaga Surya (PLTS) sebagai sumber energi alternatif karena makin berkurangnya cadangan sumber energi utama (minyak bumi, batu bara dll.) di dunia. Posisi Indonesia yang strategis di garis khatulistiwa memberi dampak positif dengan lamanya jangka waktu sinar matahari yang diterima. Pemanfaatan sinar matahari sebagai salah satu sumber energi alternatif sudah banyak dilakukan salah satu nya adalah solar home system. Kegiatan pelatihan rancang bangun pembangkit listrik tenaga surya ini diberikan kepada para santri dan santriwati sebanyak 40 orang di Pesantren Madrasah Aliyah Darussalaam Parung Bogor. Kegiatan ini bertujuan untuk mengenalkan dan memberikan ketrampilan dalam bidang perancangan sistem pembangkit listrik tenaga surya untuk rumah sederhana kepada para santri dan santriwati serta membantu membangun instalasi PLTS di Pondok Pesantren Madrasah Aliyah Darussalaam Parung Bogor. Metode yang digunakan adalah dengan melakukan presentasi dan penyuluhan kepada para santri dan santriwati dan setelah itu melakukan praktek lapangan dengan memasang PLTS di sekitar kolam penangkaran ikan lele sebagai lampu penerangan. Hasil yang diperoleh adalah berupa kemampuan para santri dan santriwati dalam merencanakan dan memasang Pembangkit Listrik Tenaga Surya sederhana secara mandiri.

Kata kunci: sel surya, pesantren, energi terbarukan 


\section{PENDAHULUAN}

Pendidikan adalah suatu proses dimana peserta didik akan memiliki pengetahuan (kognitif), sikap (apektif) dan ketrampilan (psikomotorik) yang di masa akan dating akan menjadi bekal hidup di tengah-tengah masyarakat. Proses ini mencakup peningkatan intelektual, personal dan kemampuan sosial yang diperlukan bagi siswa SMU/sederajat sehingga tidak saja berguna bagi diri pribadi dan keluarga tetapi juga keberadaannya bermanfaat bagi masyarakat [2].

Saat ini, kemampuan (skill) dalam menguasai dan mengenal teknologi dan informasi memegang peranan yang sangat penting, khususnya bagi para pelajar yang duduk di bangku sekolah. Pembelajaran teknologi dan informasi bagi pelajar SMU/sederajat menjadi pernting untuk diaplikasikan dan dilaksanakan, seiring dengan tuntutan kebutuhan penguasaan teknologi dan informasi di berbagai aspek kehidupan saat ini.

Pondok Pesantren Daarussalam Bogor yang didirikan pada tahun 1992, di atas tanah seluas $6400 \mathrm{~m}^{2}$ dan berlokasi di kampong Babulak Desa Padasuka, Bogor mempunyai santri sebanyak 70 orang santri, baik laki-laki maupun perempuan. Sebagai sebuah lembaga pendidikan, Pondok Pesantren Daarussalam Bogor diharapkan dapat memberikan pelayanannya kepada masyarakat secara maksimal, tidak hanya memiliki peranan penting sebagai lembaga penyebaran agama tetapi juga sekaligus sebagai lembaga yang dapat mencerdaskan masyarakat. Dapat dikatakan bahwa pondok pesantren memiliki tujuan ganda sebagai institusi yang mempertahankan nilai-nilai keislaman dengan titik berat pada aspek pendidikan sedangkan dalam dunia pendidikan aspek teknologi tidak bisa dipisahkan sebagai penunjang sistem belajar [3]. Oleh karena itu, kegiatan pelatihan Pembangkit Listrik Tenaga Surya (PLTS) akan dilaksanakan di pesantren Daarussalam Bogor sebagai bentuk pengenalan dunia teknologi kepada para pelajar dan sebagai wujud nyata transfer teknologi kepada masyarakat. PLTS metipakan salah satu sumber energi listrik terbarukan (renewable energy) yang sangat dibutuhkan masyarakat pada saat ini.

Energi listrik sudah menjadi kebutuhan dasar manusia pada saat ini dalam mendorong segala jenis kegiatan yang ada, seperti penerangan, transportasi umum, komunikasi dan lain sabagainya. Menurut Kementerian Energi dan Sumber Daya Mineral (ESDM) bahwa sampai September 2017 desa yang sudah teraliri listrik mencapai 73.656 desa, sedangkan sisanya ada sekitar 2.500 atau 7 persen dari total desa yang ada yang belum dialiri listrik. Disamping itu, menurut data Badan Pusat Statistik (BPS), pengadaan listrik masih di dominasi oleh PLTU (49\%), PLTGU (19,59\%) dan PLTD $(12,28 \%)$ sedangkan pembangkit listrik energi terbarukan hanya mempunyai kapasitas di bawah $12 \%$ dari total kapasitas terpasang [1]. Jadi dapat disimpulkan bahwa hampir 85\% pengadaan listrik di Indonesia masih dominasi oleh pembangkit listrik yang berbahan bakar fosil yang diperkirakan akan habis dalam jangka waktu 30 tahun mendatang. Oleh karena itu, penggunaan sumber energi terbarukan merupakan solusi dalam menjawab tantangan krisis energi yang akan terjadi di masa mendatang dan salah satunya adalah Pembangkit Listrik Tenaga Surya yang akan menjawab kebutuhan sumber energi di masa datang, terutama energi listrik. 


\section{METODE/ PERANCANGAN KEGIATAN}

Metode pelaksanaan yang digunakan dalam pelaksanaan P2M ini adalah

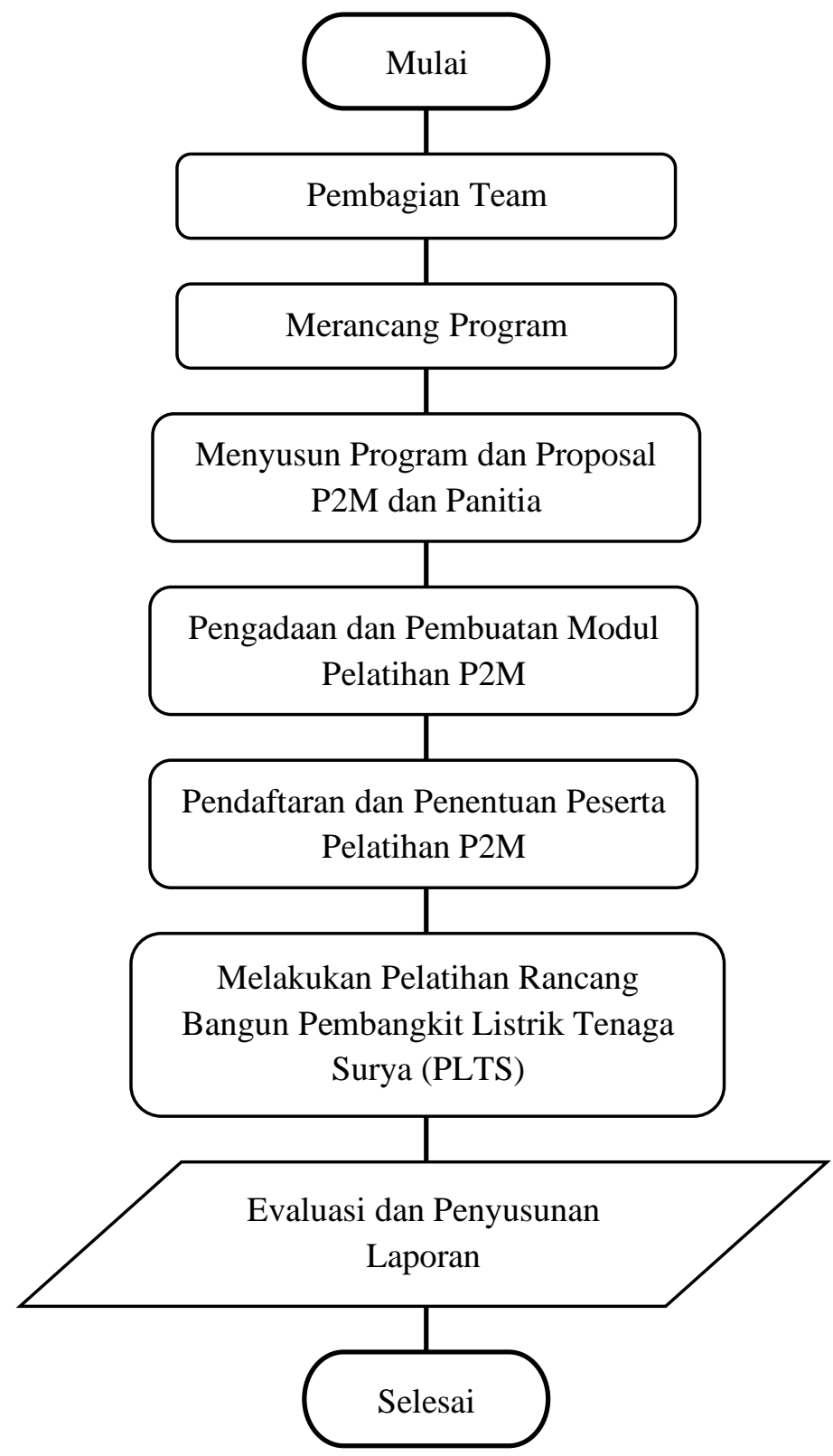

Gambar 1. Metode Pelaksanaan Kegiatan

Pelatihan rancang bangun Pembangkit Listrik Tenaga Surya (PLTS) di Madrasah Aliyah Daarussalaam Parung Bogor akan dilakukan dalam satu sesi yang akan diikuti oleh 20 - 40 siswa. Kegiatan ini dapat dilaksanakan dalam jangka waktu sekurang-kurangnya 4 (empat) hari kerja. Siswa akan diberikan materi berupa pengetahuan tentang aplikasi Pembangkit Listrik Tenaga Surya (PLTS) dan siswa diberi kebebasan bertanya tentang aplikasi PLTS, sehingga siswa benar-benar mampu menerapkan sistem PLTS sederhana dalam kehidupan sehari-hari, mengetahui potensi energi matahari, mengetahui komponen penyusun dan mampu membuat sederhana rancang bangun PLTS. Langkah 1 : Siswa diberikan teori tentang dasar-dasar PLTS 
Langkah 2 : Penyajian dan peragaan alat rangkaian dan komponen-komponen PLTS

Langkah 3 : Simulasi aplikasi PLTS di Madrasah dengan menggunakan miniatur PLTS yang telah disiapkan

Langkah 4 : Siswa-siswa diberi kesempatan untuk melakukan simulasi sendiri dengan menggunakan miniatur PLTS yang telah disiapkan.

Langkah 5 : Madrasah diberikan miniatur PLTS untuk penunjang pembelajaran bagi siswasiswi dan penerangan bagi kegiatan di madrasah.

\section{HASIL DAN PEMBAHASAN}

Kegiatan kemitraan dengan tema pelatihan rancang bangun pembangkit listrik tenaga surya di Madrasah Aliyah Darussalaam Parung Bogor ini diberikan secara gratis kepada santri-santriwati untuk kedua kalinya dalam pelaksanaan pengabdian masyarkat. Kegiatan ini dilakukan dua sesi dimana sesi pertama pertama siswa diberikan teori tentang dasar- dasar tentang PLTS dan simulasi aplikasi PLTS dengan menggunakan miniatur PLTS yang telah disiapkan kemudian lanjut sesi kedua dengan pemasangan miniatur PLTS sebagai penunjang pembelajaran dan penerangan bagi kegiatan di Madrasah Aliyah Darussalaam Parung Bogor.

Kegiatan di awali dengan pembukaan yang diisi dengan sambutan dari pihak pesantren dan dari pihak STT-PLN. Dari pihak STT-PLN menjelaskan secara umum kegiatan yang akan dilakukan dan dari pihak pesantren mengucapkan terima kasih atas kegiatan yang diberikan oleh STT-PLN. Kegiatan ini di hadiri oleh 37 siswa dengan jumlah santri putra 15 orang dan santri putri 22 orang. Kegiatan dilakukan di aula pesantren seperti pada Gambar di bawah.

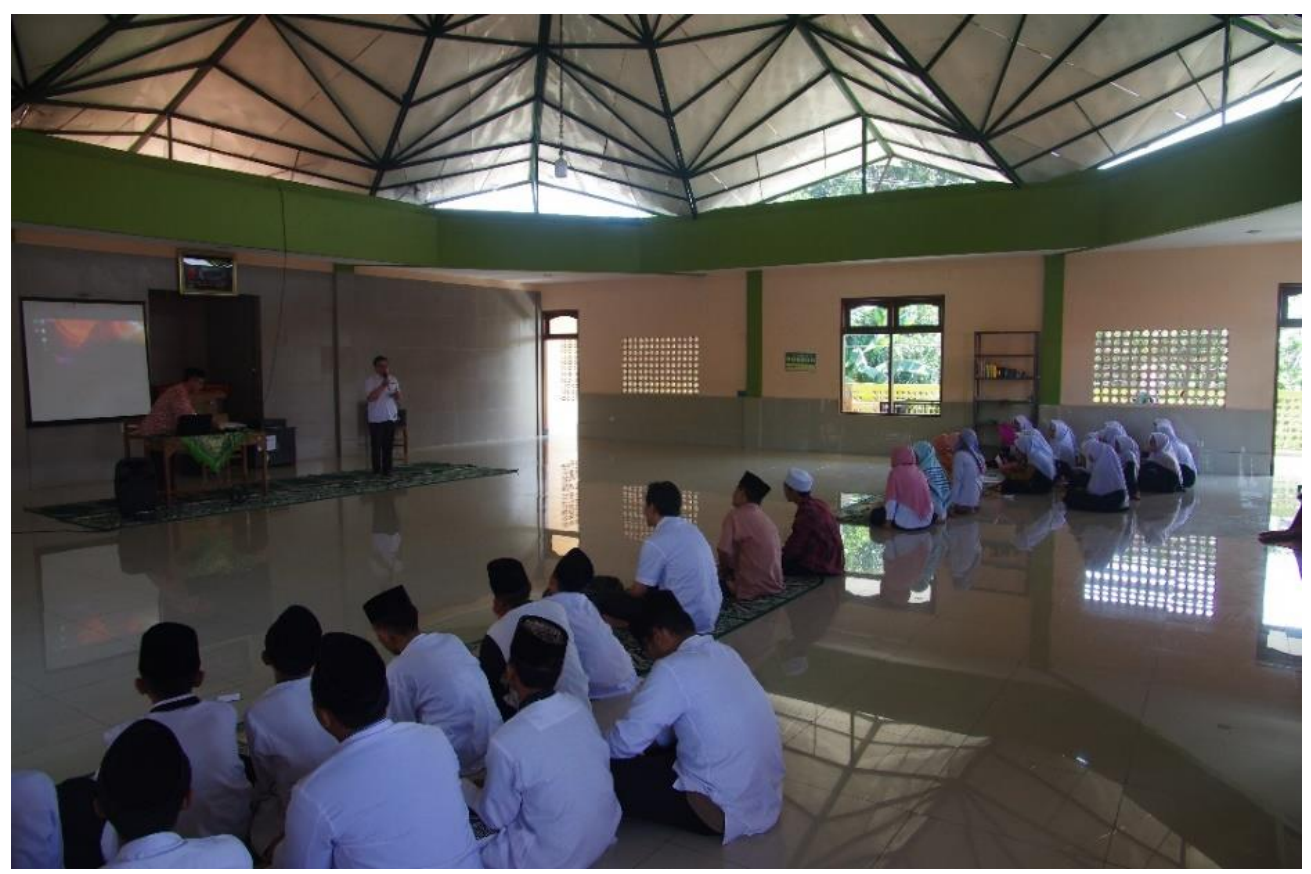

Gambar 2. Sambutan dari pihak dosen STT - PLN 


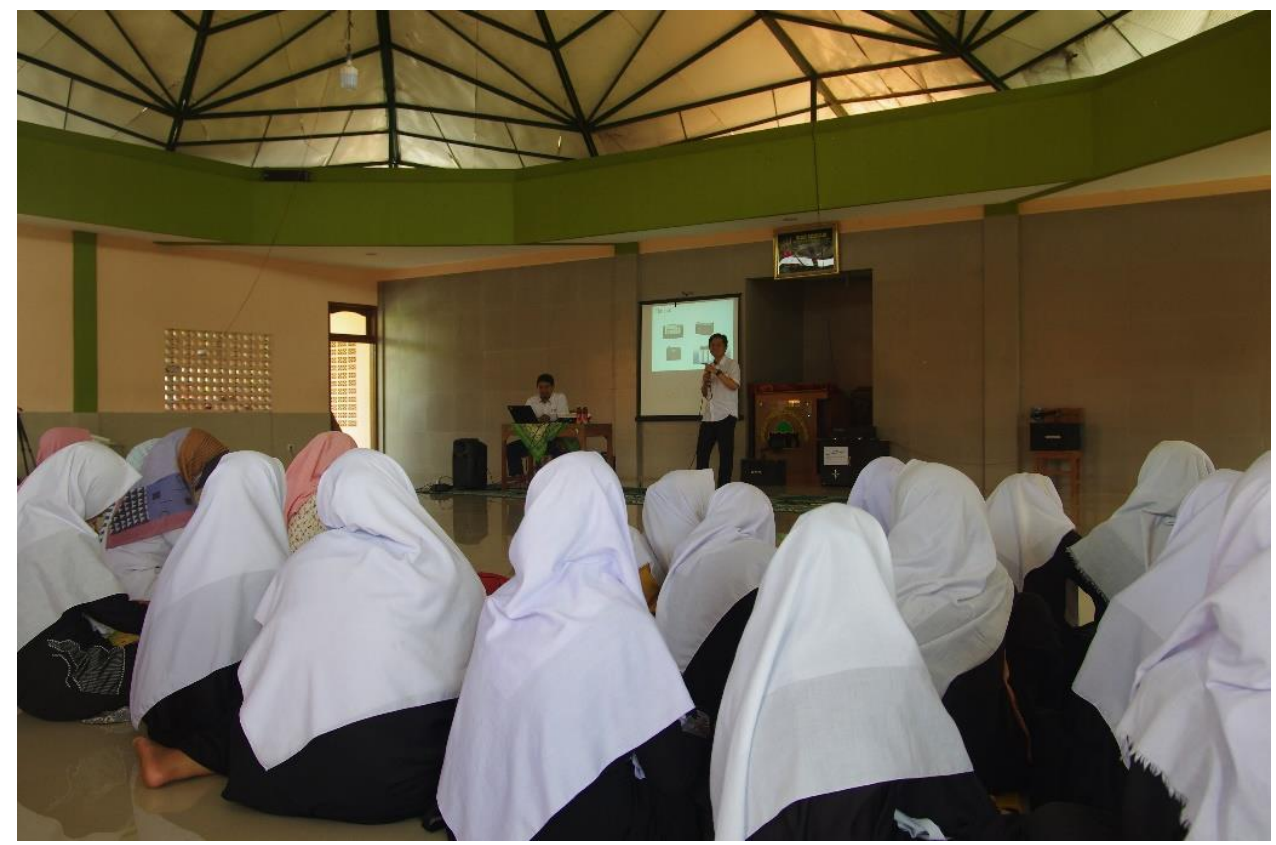

Gambar 3. Penjelasan materi tentang PLTS

Setelah proses pembukaan selesai dilakukan proses penjelasan tentang PLTS dan teori dasar pengenalan tenaga surya bekerja, dimana 37 orang santri dan santriwati mendengarkan penjelasan yang didampingi oleh 4 orang dosen. Pada sesi penyajian dan peragaan alat dilakukan dengan melakukan demo dengan menggunakan panel surya dengan lampu sebagai indikator bahwa panel surya berfungsi dengan baik seperti pada gambar di bawah ini.

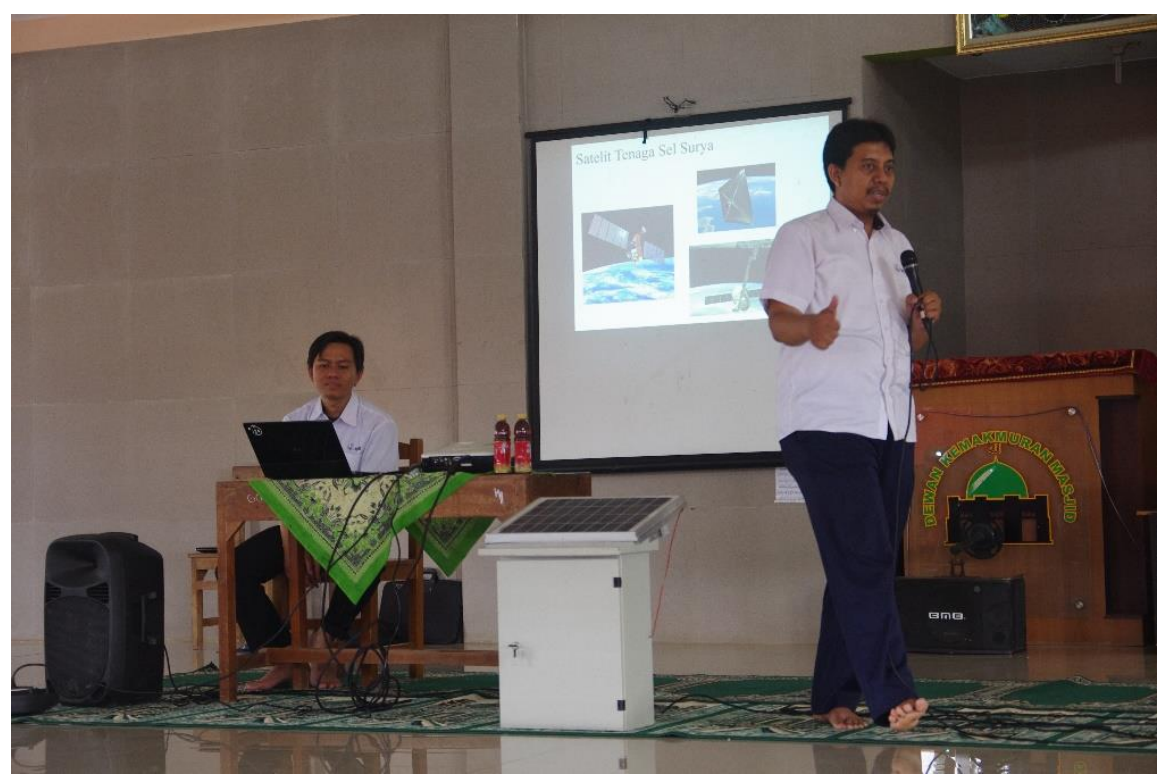

Gambar 4. Melakukan demo cara kerja PLTS

Supaya para santri dan santriwati lebih memahami maka dibagikan beberapa modul sederhana dari panel surya dengan menghubungkan led sebagai indikatornya kemudian dirakit dengan 
menyambungkan kutub positif led ke kutub positif modul sel surya dan kutub negatif led ke kutub negatif modul sel surya seperti gambar dibawah ini.

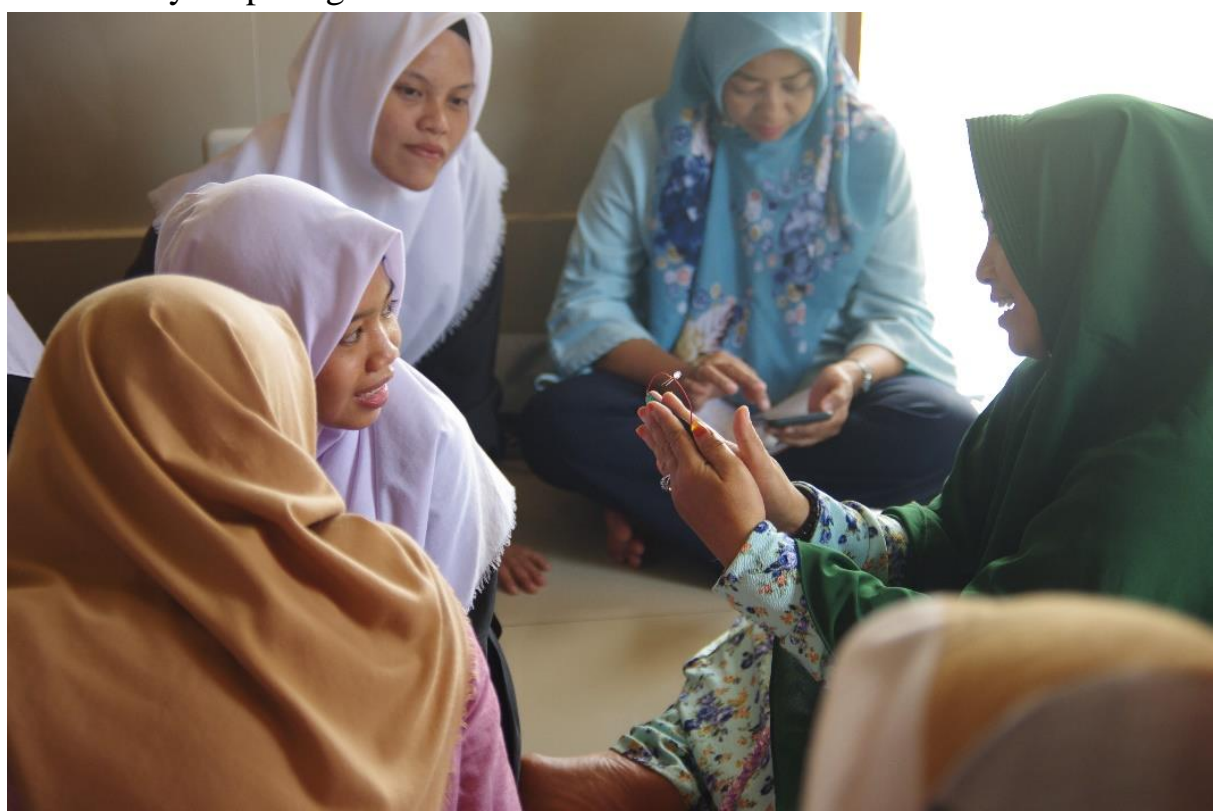

Gambar 5. Perancangan modul sederhana dari panel surya dengan led yang dilakukan oleh santriwati

Setelah sesi penjelasan teori-teori dasar, demo penggunaan PLTS dan merancang modul sederhana panel surya dengan led. Kemudain sesi terakhir pemasangan lampu menggunakan teknologi sederhana PLTS di kolam lele di pesanteren sebagai salah satu pengaplikasian secara langsung dari pelatihan tentang rancang bangun pembangkit listrik tenaga surya.

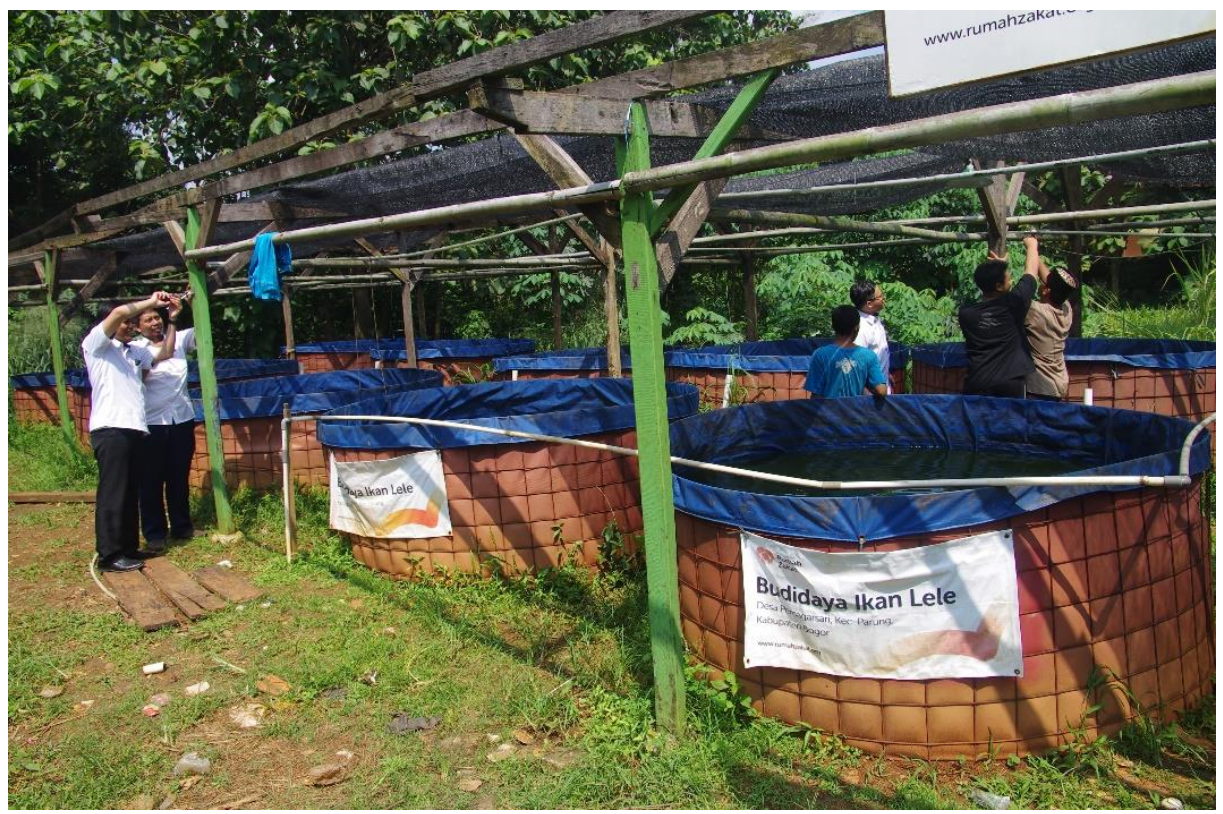

Gambar 6. Pemasangan lampu berteknologi sel surya di kolam lele Madrasah Aliyah Darussaalam

Diakhiri kegiatan para pesantren berfoto bersama dengan dan guru pendamping seperti pada gambar dibawah ini. 


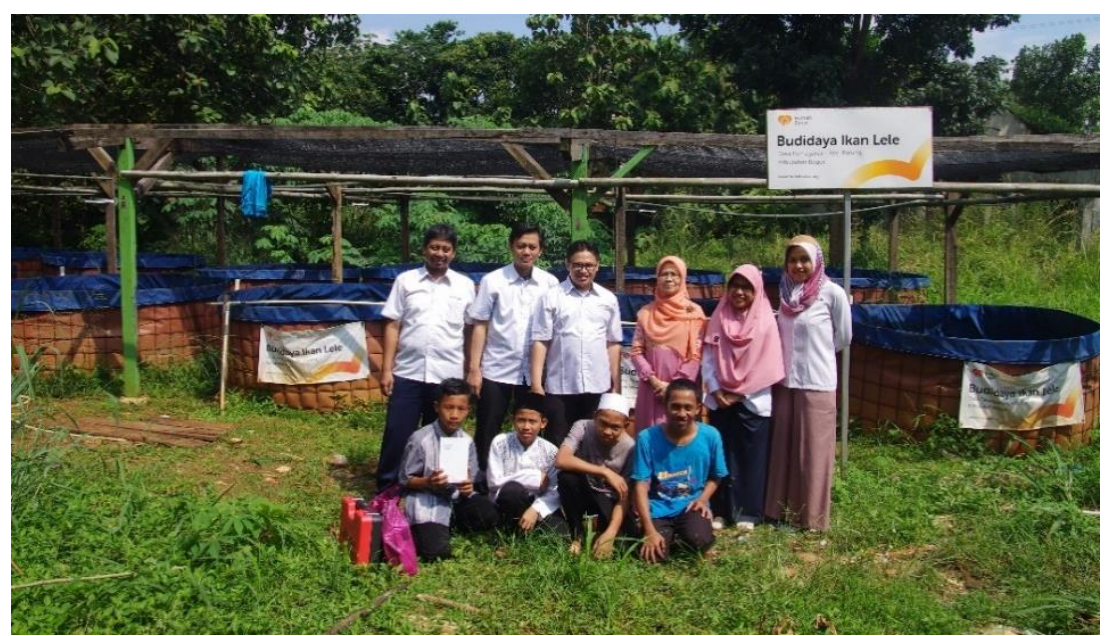

Gambar 7. Foto bersama dengan guru pendamping dan pemillik pesantren

\section{KESIMPULAN}

Dengan diadakannya kegiatan ini, santri dari pondok pesantren Daarussalaam dapat meningkatkan pengetahuannya tentang teknologi energi terbarukan menggunakan energi sinar matahari, dalam hal ini adalah modul panel surya sederhana.

\section{SARAN}

Pada kegiatan kali ini terdapat beberapa saran yang perlu dilakukan untuk kegiatan selanjutnya, antara lain :

1. Penyajian materi teori dasar yang di sampaikan lebih sederhana agar santri dan santriwati lebih mudah memahami untuk tingakt kemampuan sekolah menengah pertama dan sekolah menengah atas.

2. Percobaan menggunakan modul panel surya tidak hanya led tetapi perancangan panel surya yang dapat difungsikan dengan lampu penerangan jalan atau ruangan tidak hanya led

3. Perdalam tentang bagaimana perancangan panel surya sederhana yang bisa diaplikasikan dalam kehidupan sehari-hari para santri dan santriwati.

\section{UCAPAN TERIMA KASIH}

Ucapan terima kasih disampaikan kepada mitra dalam hal ini Pondok Pesantren Daarussalaam yang menyediakan waktu dan tempat kegiatan, STT-PLN melalui LPPPM dan Program Studi Teknik Elektro yang mendukung serta mendanai kegiatan PKM. Semoga kegiatan semacam ini dapat terus dilanjutkan dan ditingkatkan demi terciptanya masyarakat yang sejahtera, adil dan makmur dengan memanfaatkan teknologi terutama energi terbarukan.

\section{DAFTAR PUSTAKA}

[1] I. N. S. Kumara, "Pembangkit Listrik Tenaga Surya Skala Rumah Tangga Urban Dan," Teknol. Elektro, vol. 9, no. July 2010, pp. 68-75, 2017.

[2] Hamruni, \& Ricky, S. (2016). EKSISTENSI PESANTREN DAN KONTRIBUSINYA DALAM PENDIDIKAN KARAKTER. Jurnal Pendidikan Agama Islam, XIII(2).

[3] Muhakamurrohman, A. (2014). PESANTREN:SANTRI, KIAI, DAN TRADISI. Jurnal Kebudayaan Islam, 12(2), 109. 